\title{
TEKNOLOGI TEPAT GUNA: PEMANFAATAN KULIT KOPI SEBAGAI ALTERNATIF MEDIA TUMBUH JAMUR TIRAM
}

\section{APPROPRIATE TECHNOLOGY: UTILIZATION OF COFFEE LEATHER AS AN ALTERNATIVE MEDIA FOR OTHER MUSHROOM GROWING}

\author{
Dimas B. Zahrosa ${ }^{1 *)}$ Djoko Soejono $^{2)}$, Sugeng Raharto ${ }^{3)}$ Setiyono $^{4)}$ \\ ${ }^{1}$ Program Studi Agribisnis Fakultas Pertanian Universitas Jember \\ ${ }^{4}$ Program Studi Ilmu Pertanian Perkebunan Fakultas Pertanian Universitas Jember \\ *Email: dimaszahrosa.faperta@unej.ac.id
}

\begin{abstract}
Abstrak : Desa Sidomulyo merupakan salah satu desa yang berada di Kecamatan Silo Kabupaten Jember. Penjualan kopi dilakukan petani dalam proses pasca panen olah kering maupun olah basah yang menghasilkan limbah kulit kopi yang berlimpah. Limbah kulit kopi hanya sebatas di jual pada pabrikan pakan ternak dengan harga yang sangat murah dan hanya sebagian kecil yang diolah menjadi pupuk organik. Tujuan dari kegiatan pengabdian kepada masyarakat ini adalah optimalisasi pemanfaatan limbah kulit kopi untuk media budidaya jamur tiram. Metode pengabdian kepada masyarakat ini adalah sosialisasi, pelatihan, pendampingan dan konsultasi serta bantuan bag log sebagai media tumbuh dan bibit jamur tiram. Hasil yang diperoleh dari kegiatan ini antara lain pelatihan teknik budidaya jamur, pemberian bantuan bag log dan pembuatan rak susun, pendampingan budidaya dan pemanenan, pendampingan pengemasan dan pemasaran jamur.
\end{abstract}

Kata Kunci: Kopi, Jamur Tiram, Bag log, Sosialisasi, Pelatihan

\begin{abstract}
Sidomulyo Village is one of the villages located in Silo District, Jember Regency. The sale of coffee is carried out by farmers in the post-harvest process of dry processing or wet processing which produces abundant coffee husk waste. Coffee skin waste is only sold to animal feed manufacturers at a very cheap price and only a small portion is processed into organic fertilizer. The purpose of this community service activity is to optimize the use of coffee husk waste for oyster mushroom cultivation media. This community service method is socialization, training, mentoring and consultation as well as bag log assistance as a growing medium and oyster mushroom seeds. The results obtained from this activity included training on mushroom cultivation techniques, providing bag log assistance and making stacking racks, assisting cultivation and harvesting, assistance in mushroom packaging and marketing.
\end{abstract}

Keywords: Coffee, Mushrooms, Bag log, Socialization, Training 
INTEGRITAS : Jurnal Pengabdian

Vol 5 No 1 Juli 2021

ISSN 2580-7978 (cetak) ISSN 2615-0794 (online)

\section{PENDAHULUAN}

Desa Sidomulyo merupakan salah satu desa yang berada di Kecamatan Silo Kabupaten Jember. Desa Sidomulyo memiliki kelompok tani yang paling aktif dalam mengembangkan komoditas kopi robusta di Kabupaten Jember. Kelompok tani tersebut yaitu kelompok tani sidomulyo 1. Kelompok tani ini menjual kopi robusta melalui koperasi atau pedagang kecil, dalam bentuk biji atau mentah dan sebagian dilakukan proses pengolahan bubuk. Penjualan kopi dilakukan petani dalam proses pasca panen olah kering maupun olah basah. Untuk olah kering yang umumnya menghasilkan kopi asalan dengan kualitas yang kurang baik, menyebabkan harga yang diterima petani relatif rendah. Sedangkan hanya sebagian kecil petani yang menerapkan proses pasca panen olah basah.

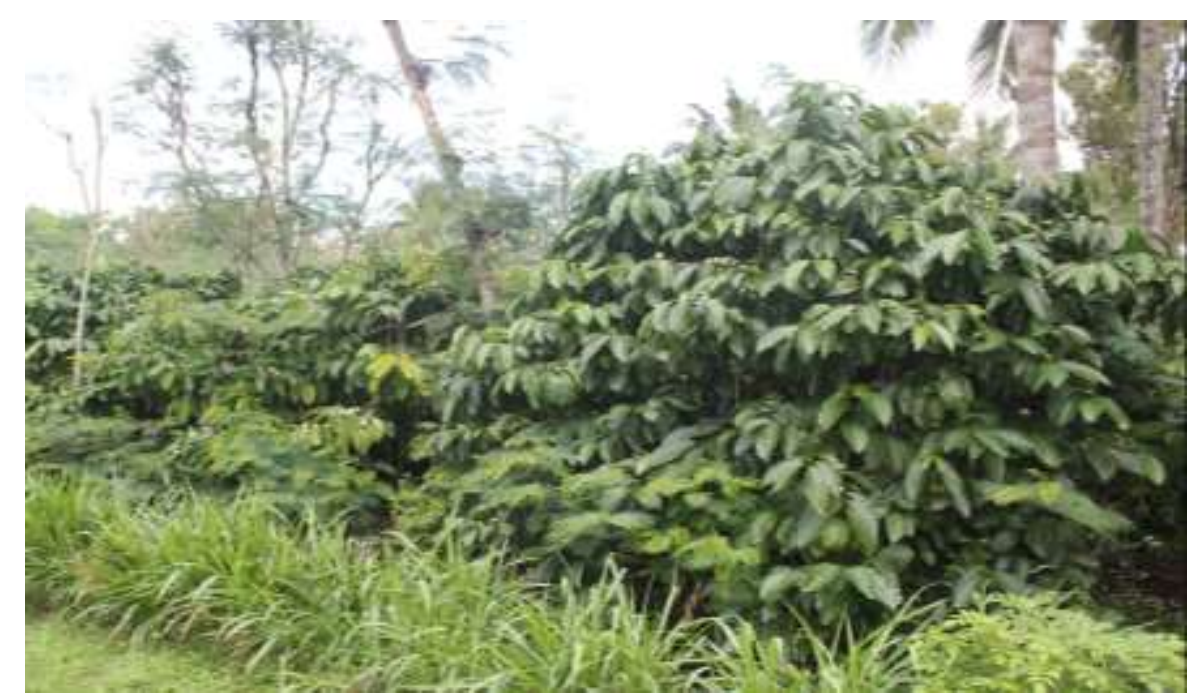

Gambar 1. Tanaman kopi robusta di desa sidomulyo

Proses pasca panen komoditas kopi dengan olah kering maupun olah basah selain menghasilkan biji kopi, juga menghasilkan limbah kulit kopi yang berlimpah. Tidak banyak pilihan bagi masyarakat untuk memperoleh tambahan pendapatan bagi keluarga. Komoditas kopi termasuk komoditas tahunan, yang panennya tidak terjadi sepanjang tahun. Umumnya, komoditas kopi dengan kondisi iklim yang baik, mulai belajar panen sekitar Bulan Juni, puncaknya pada Bulan Agustus dan berakhir sekitar Bulan Oktober. Kondisi demikian, menyebabkan tidak banyak pilihan bagi masyarakat untuk menambah pendapatan, utamanya di musim saat menunggu komoditas kopi panen. 
Fakta dilapang bahwa limbah kulit kopi hanya sebatas di jual pada pabrikan pakan ternak dengan harga yang sangat murah dan hanya sebagian kecil yang diolah menjadi pupuk organik. Oleh karena itu, melalui Program Pengabdian Kepada Masyarakat Berbasis Pengembangan Desa Binaan, maka dibutuhkan upaya optimalisasi pemanfaatan limbah kulit kopi untuk media budidaya jamur tiram.

\section{METODE}

Kegiatan akan dilaksanakan di wilayah Desa Sidomulyo yang berlokasi di Kecamatan Silo Kabupaten Jember. Kegiatan dan program peningkatan ekonomi masyarakat Desa Sidomulyo melalui sosialisasi, pelatihan, pendampingan dan konsultasi serta bantuan bag log sebagai media tumbuh dan bibit jamur tiram. Kegiatan dilaksanakan pada bulan November - Desember 2020. Sasaran kegiatan ini adalah masyarakat yang tergabung dalam kelompok tani kopi di Desa Sidomulyo Kecamatan Silo.

\section{HASIL DAN PEMBAHASAN}

\section{Kegiatan Survey dan Sosialisasi}

Kegiatan survey dan sosialiasi dilaksanakan di awal kegiatan pada peserta sasaran yaitu masyarakat Desa Sidomulyo khususnya petani kopi. Inti dari sosialisasi adalah (1) menyampaikan maksud dan tujuan dari kegiatan pengabdian; (2) hal-hal yang dibutuhkan dalam rangkaian kegiatan pengabdian; (3) Metode pengabdian yang nantinya akan dilaksanakan dan (4) bentuk dukungan dan keberlanjutan dari kegiatan pengabdian. Sosialisasi dilaksanakan dengan melakukan pertemuan dengan tokoh masyarakat, terutama petani kunci yang memahami persoalan tentang potensi dan permasalahan pengembangan kopi. 

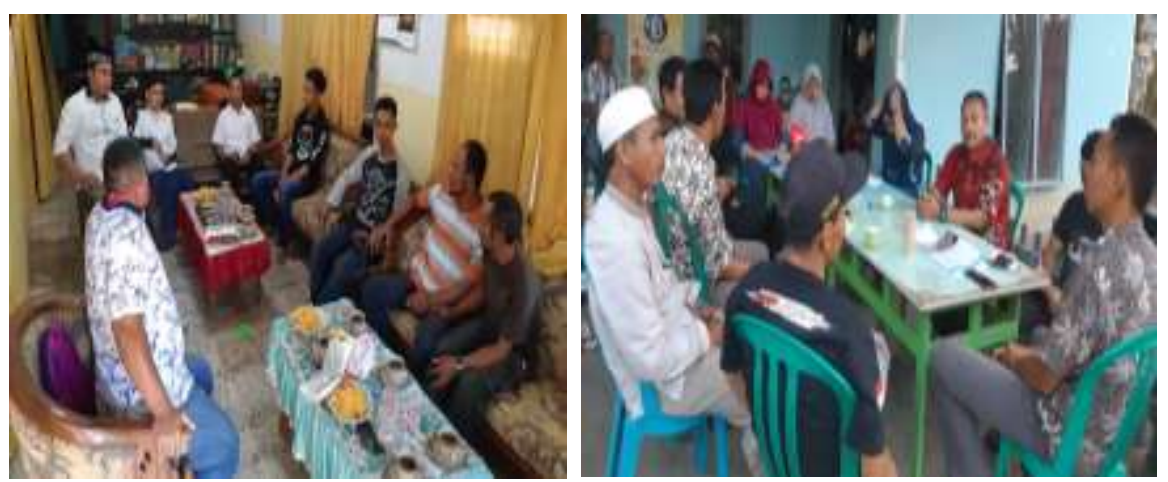

Gambar 2. Kegiatan sosialisi pada pemuda dan wanita tani

Beberapa informasi yang diperoleh dari kegiatan sosialisasi antara lain sebagai berikut:

1. Pada saat musim panen kopi saat itulah kulit kopi yang sudah diolah dan terlepas dari biji kopi sangat banyak sekali dan akan menjadi limbah yang sebenarnya sangat berpotensi untuk dikembangkan.

2. Selama ini kulit kopi hanya sebagai bahan tambahan pakan ternak kambing maupun sapi bagi petani yang memiliki ternak tersebut.

3. Petani belum bisa memanfaatkan peluang bagaimana kulit kopi tersebut dapat menghasilkan uang tambahan jika diolah dengan baik menjadi produk yang bernilai jual tinggi.

4. Petani merespon baik terkait kegiatan pengabdian yang akan dilakukan oleh tim dari Lembaga Penelitian dan Pengabdian Kepada Masyarakat.

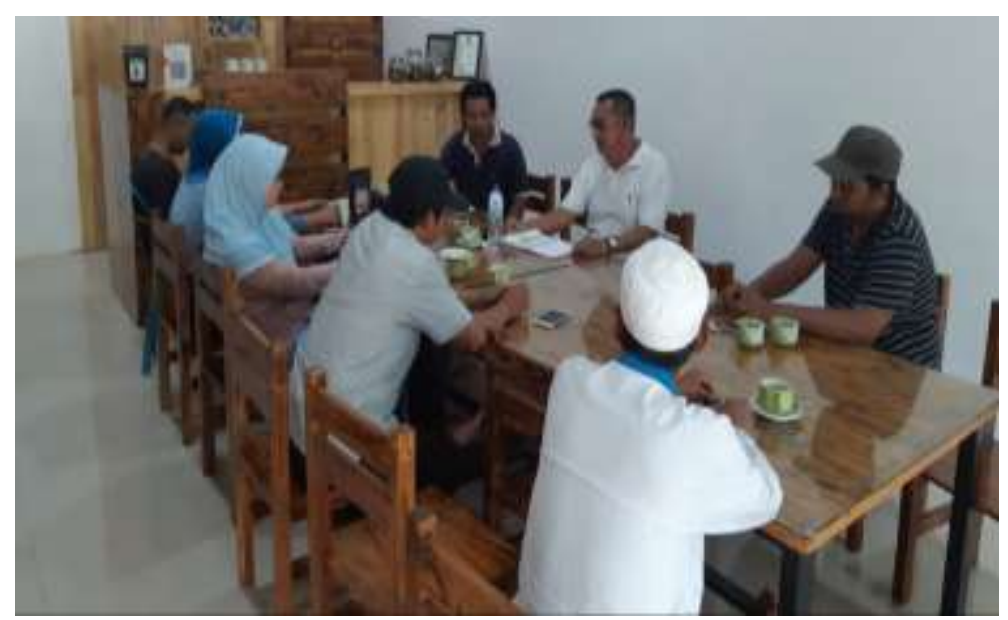

Gambar 3. Kegiatan sosialisi pada pengurus koperasi buah ketakasi 


\section{Pelatihan Teknik Budidaya Jamur}

Pada tahap kedua ini dilakukan pelatihan, pendampingan dan konsultasi teknik budidaya jamur tiram menggunakan limbah kulit kopi sebagai media tumbuh. Potensi kulit kopi di Desa Sidomulyo Kecamatan Silo sangat besar. Selama ini limbah kulit kopi hanya dijual kepada pabrik pakan ternak dengan harga yang murah berkisar harga Rp. 200-400 rupiah per Kg saja. Maka dari itu kegiatan pengabdian ini diarahkan untuk memberikan pengetahuan dan keterampilan pada masyarakat atau petani kopi agar bisa memanfaatkan peluang usaha yang berbasis jamur tiram dengan media tumbuh jamur yang berasal dari limbah kulit kopi.

Pelatihan teknik budidaya jamur tiram diawali pembekalan bagi sasaran mitra dengan memberikan pengetahuan cara membuat bag log media tumbuh jamur tiram dengan bahan utama yaitu limbah kulit kopi. Kegiatan ini dilakukan di Desa Karangharjo Kecamatan Silo. Dari tim memilih Desa Karangharjo dikarenakan disana sudah dilakukan budidaya yang intesif terkait jamur tiram mulai tahun 2014. Di Desa Karangharjo ini petani kopi Sidomulyo belajar memahami bagaimana cara membuat bag log jamur dengan media tumbuh menggunakan libah kulit kopi. Beberapa petani yang hadir diacara pelatihan ini sangat antusias sekali. Respon positif diberikan oleh mereka bahwasanya dengan memanfaatkan limbah kulit kopi yang selama ini hanya dijual dengan harga murah kepada pabrik pakan ternak dapat dimanfaatkan secara langsung oleh petani untuk pembuatan bag log media tumbuh jamur.
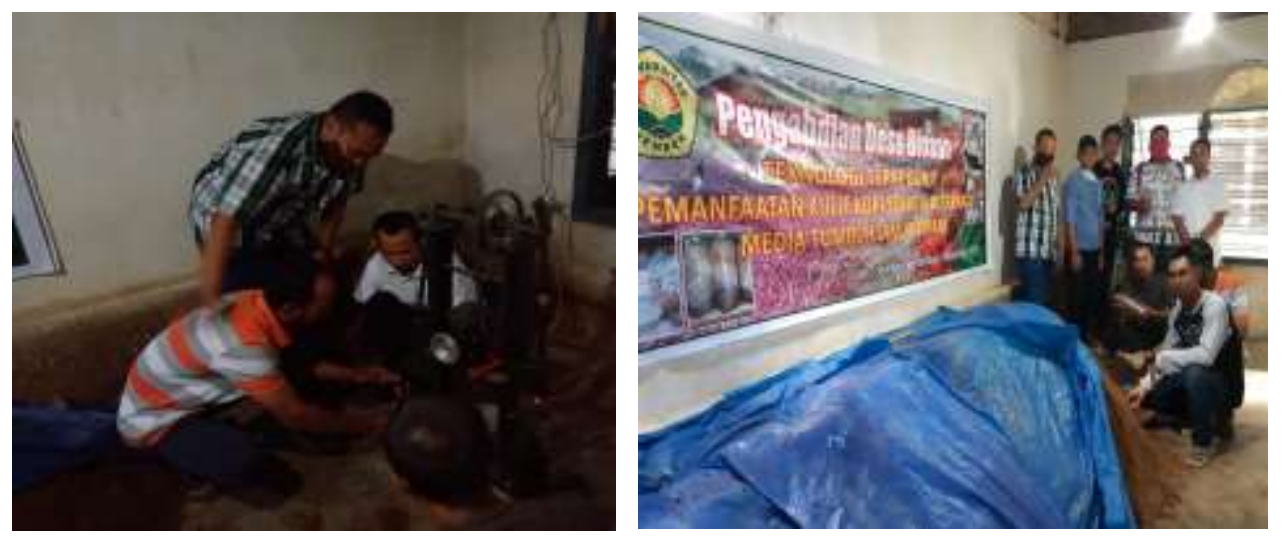

Gambar 4. Kegiatan pelatihan pembuatan bag log jamur 
Alat yang digunakan dalam pembuatan bag log antara lain kompor, sekop, plastik tahan panas, karet, kertas, timbangan dan sprayer. Bahan yang dibutuhkan adalah kulit kopi sebagai bahan utamanya, serbuk gergaji kayu sengon, jerami padi dan, bibit produksi jamur tiram. Proses pengisian bag log dilakukan pencacahan kulit kopi dan jerami padi terlebih dahulu, kulit kopi dan jerami padi yang dicacah dicampur dengan serbuk gergaji kayu sengon dan air sampai kulit kopi dan jerami menggumpal. Setelah melihat bahan semuanya yang dicampur terlihat menggumpal tersebut dicampur dengan bibit kemudian dimasukkan ke plastik media tanam kemudian dipres sampai padat menggunakan alat pengepres. Bag log yang sudah terisi disusun di rak kayu atau bambu sampai tumbuh jamur.

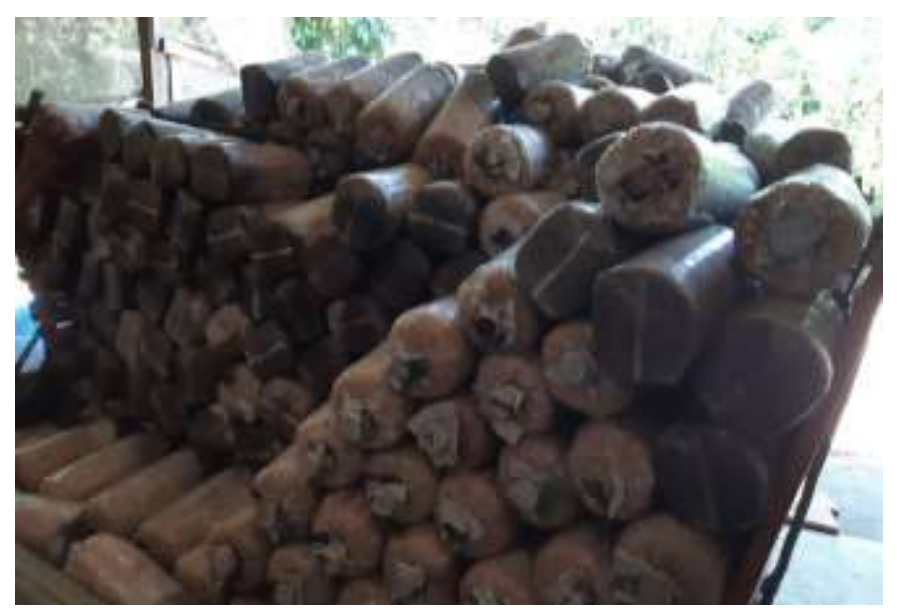

Gambar 5. Bag log jamur tiram berbahan kulit kopi

\section{Pemberian Bantuan Bag log dan Pembuatan Rak Susun}

Setelah masyarakat atau petani kopi di Desa Sidomulyo diberikan pemahaman dan keterampilan melalui pelatihan, pendampingan serta konsultasi teknik budidaya jamur tiram, maka akan disalurkan bantuan bag log sebagi media tumbuh jamur tiram. Bag log yang disalurkan kepada mitra adalah bag log yang diolah masyarakat atau petani kopi bersama instruktur pembuatan bag log dengan bahan utama yaitu limbah kulit kopi. Pemberian bantuan bag log langsung diberikan pada pemuda dan wanita tani di Desa Sidomulyo. Bantuan bag log yang diberikan berjumlah 1.500 bag log yang sudah siap dibudidayakan. 

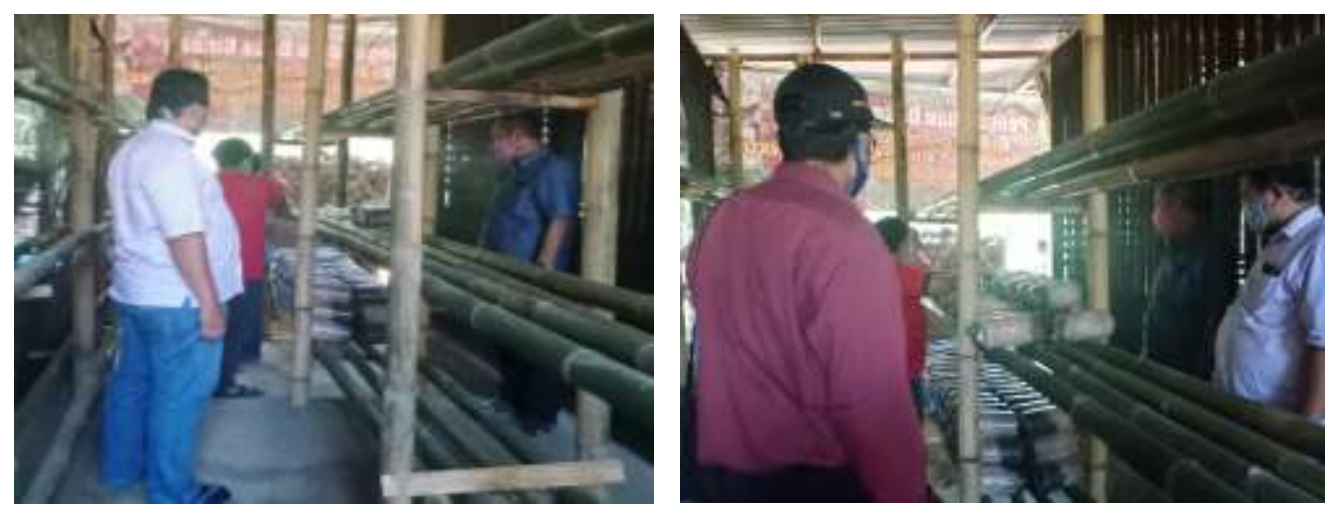

Gambar 6. Bag log jamur tiram berbahan kulit kopi yang didistribusikan kepada pemuda dan wanita tani

Lokasi pengusahaan komoditas jamur tiram harus bersih sehingga dapat mendukung dalam keberhasilan budidaya jamur tersebut. Pada proses budidaya jamur terdapat kumbung sebagai tempat aktivasi budidaya jamur mulai dari proses pembuatan bag log, menumbuhkan miselia sampai menumbuhkan tubuh buah jamur. Penempatan posisi kumbung jamur tersebut jauh dari tempat sampah atau tempat peternakan. Hal tersebut demikian karena untuk mencegah timbulnya berbagai hama dan penyakit pada jamur. Lokasi pembuatan kumbung jamur tidak jauh dari lokasi pemasaran. Hal tersebut demikian karena dapat meminimalkan biaya transportasi dan juga dapat mencegah penurunan kualitas jamur.

Selain memberikan bantuan bag log Tim dari Universitas Jember juga memberikan bantuan berupa rak susun yang digunakan untuk meletakkan bag log. Kumbung yang dibuat sesuai dengan kebutuhan, ruang pertumbuhan yang dibuat sesuai dengan jumlah bag log yang ditampung. Di dalam kumbung tersebut dilengkapi dengan rak berupa kisi-kisi yang dibuat bertingkat. Rak tersebut berfungsi untuk menyusun bag log. Rangka rak dibuat dari bambu dan diletakkan berjajar. Antara rak satu dengan yang lain dipisahkan oleh lorong untuk perawatan. Peletakan bag log diatas rak dengan posisi tidur (horisontal). Alat utama dalam ruang pertumbuhan adalah rak bambu dan spray untuk penyiraman atau pengabutan. 

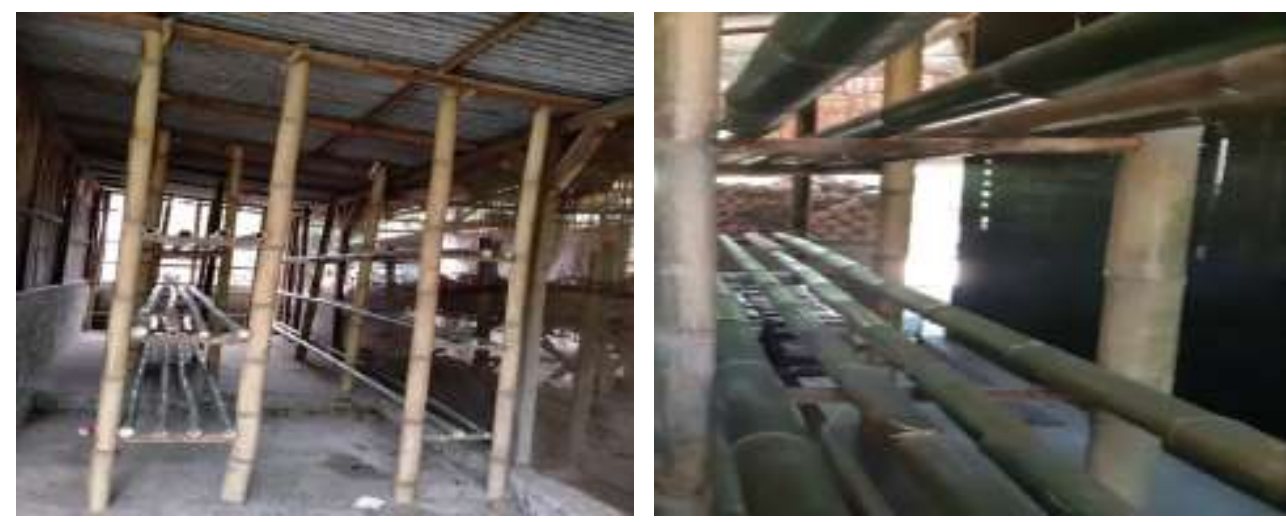

Gambar 7. Rak susun yang terbuat dari bambu yang didistribusikan kepada pemuda dan wanita tani

\section{Pendampingan Budidaya dan Pemanenan Komoditas Jamur Tiram}

Pendampingan budidaya sampai proses panen perlu dilakukan agar hasil produk jamur bisa maksimal. Pada tahap ini masyarakat atau petani kopi di Desa Sidomulyo diberikan bekal materi terlebih dahulu terkait dengan cara bagaimana melakukan budidaya jamur yang baik dan benar. Selain itu juga pemahaman materi terkait dengan proses pemanenan jamur tiram perlu diberikan pada sasaran mitra. Hal ini sangat diperlukan dikarenakan jika proses pemanenan salah maka akan berpengaruh pada produktivitas hasil jamur tiram selanjutnya.

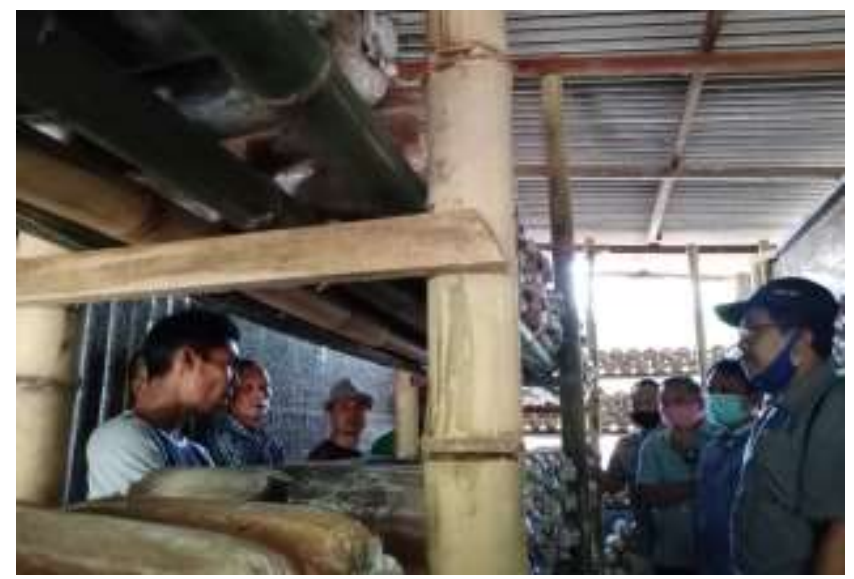

Gambar 8. Penyampaian materi langsung di kumbung jamur

Pemeliharaan budidaya jamur tiram adalah tahap yang dimulai sejak pemutihan sampai bag log tidak lagi berproduksi. Kelembapan lingkungan dipertahankan dengan menyemprot menggunakan sprayer. Penyemprotan air dilakukan secara intensif khususnya pada musim kemarau, para petani nantinya 
harus melakukan penyemprotan dua kali sehari, pagi dan sore hari. Jika sudah memasuki musim hujan penyemprotan harus dikurangi, hanya dilakukan penyemprotan sekali sehari, yaitu pada sore hari.

Tubuh buah yang sudah cukup mekar dapat dipanen. Panen dilakukan setelah tubuh buah mencapai ukuran maksimal saat 2-3 hari setelah tumbuh bakal tubuh buah. Pemanenan dilakukan pada pagi hari agar kesegaran jamur dapat lebih dipertahankan serta mempermudah pemasaran. Pemanenan dilakukan terhadap jamur yang telah mekar dan membesar. Pengambilan jamur harus dilakukan dari pangkal batang karena batang yang tersisa dapat mengalami kebusukan. Potong jamur dengan pisau yang bersih dan tajam. Panen dilakukan setiap hari atau beberapa hari sekali, tergantung dari jarak pembukaan log-log. Dari satu bag log akan dihasilkan sekitar 0,8-1 kg jamur.

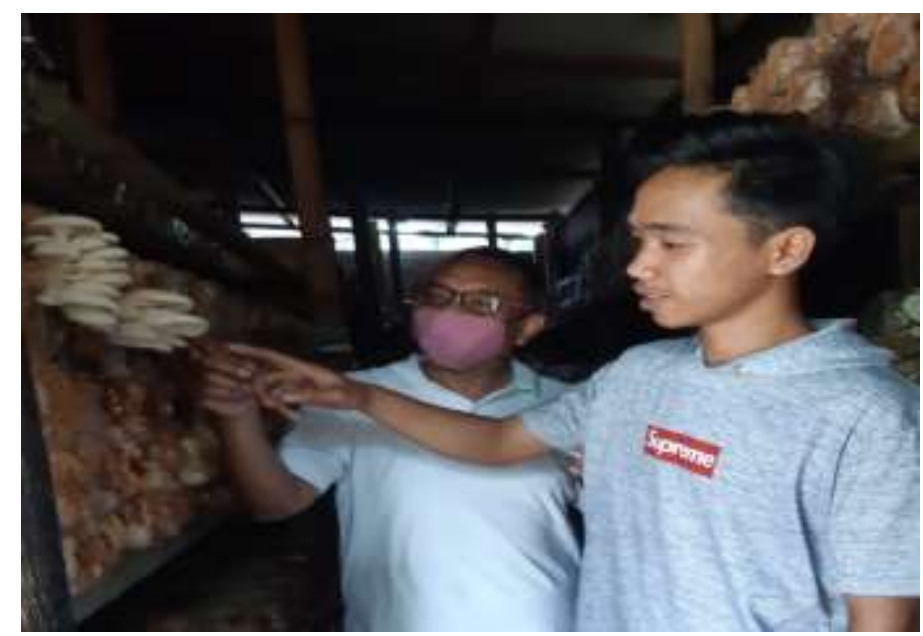

Gambar 9. Hasil produksi jamur tiram yang siap di panen

\section{Pendampingan Pengemasan dan Pemasaran Komoditas Jamur Tiram}

Kegiatan pengabdian ini bertujuan untuk mngembangkan potensi unggulan komoditas pertanian di desa mitra. Masyarakat atau petani kopi di Desa Sidomulyo dapat memaksimalkan potensi yang dimilikinya untuk bisa menjadikan peluang usaha baru. Pemanfaatan limbah kulit kopi untuk dijadikan sebagai bahan alternatif dalam pembuatan media tanam jamur tiram merupakan Teknologi Tepat Guna yang dapat dimanfaatkan oleh petani kopi di Desa Sidomulyo. Pelatihan dan pendampingan mulai dari tahap pembuatan bag log sampai proses bagaimana produk jamur tiram ini layak untuk dipasarkan perlu 
dilakukan oleh tim. Pada tahap ini merupakan tahap pendampingan terakhir yaitu pengemasan dan pemasaran. Proses pengemasan yang baik nantinya akan dapat menarik minat konsumen untuk membeli.

Kegiatan pasca pemanenan harus diperhatikan untuk menjaga kualitas jamur tiram agar sampai kepada konsumen dengan kondisi yang benar-benar baik serta tidak mengecewakan konsumen, beberapa hal yang perlu dilakukan adalah:

1. Dilakukan seleksi/penyortiran jamur pisahkan jamur yang rusak dengan jamur yang baik, jamur yang baik memiliki ciri-ciri besar, kering, putih bersih dan bebas dari hama penyakit.

2. Dilakukan pengepakan, Masukkan jamur yang telah disortir kedalam kantong plastik (sesuaikan ukuran plastik dengan kebutuhan konsumen) atau dapat menggunakan cawan styrofoam dan ditutup dengan plastik Film.

3. Jika dibutuhkan penyimpanan sementara jamur tiram dimasukkan kedalam pendingin/kulkas pada suhu $10-15^{\prime} \mathrm{c}$, untuk menjaga kesegaran jamur dan menambah masa simpan.
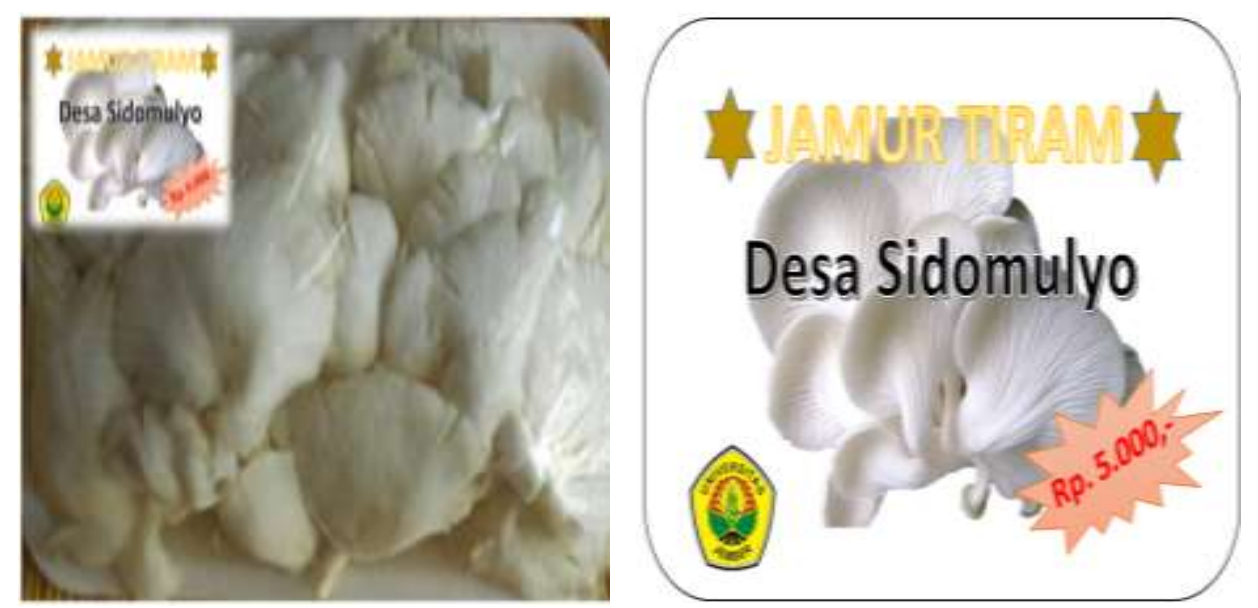

Gambar 10. Logo dan Kemasan Jamur Tiram

Untuk sementara kemasan yang digunakan dalam memasarkan jamur tiram hasil budidaya para petani kopi yaitu dengan cara dikemas menggunakan cawan styrofoam dan ditutup dengan plastik film dan diberi logo. Harga jual jamur tiram yang diberikan petani sebesar Rp. 5.000,- dengan berat bersih 0,25 $\mathrm{Kg}$. Dengan harga yang relatif murah tersebut dapat dijangkau semua kalangan. Pemasaran yang selama ini dilakukan masih terbatas di wilayah Desa 
Sidomulyo baik dilakukan secara offline maupun online dengan menggunakan aplikasi Whatsapp. Harapan kedepan dari petani yaitu adanya pelatihan terkait pengolahan jamur tiram yang dapat meningkatkan harga jual. Misalnya dalam bentuk pelatihan pembuatan bakso jamur, keripik jamur dan lain sebaginya.

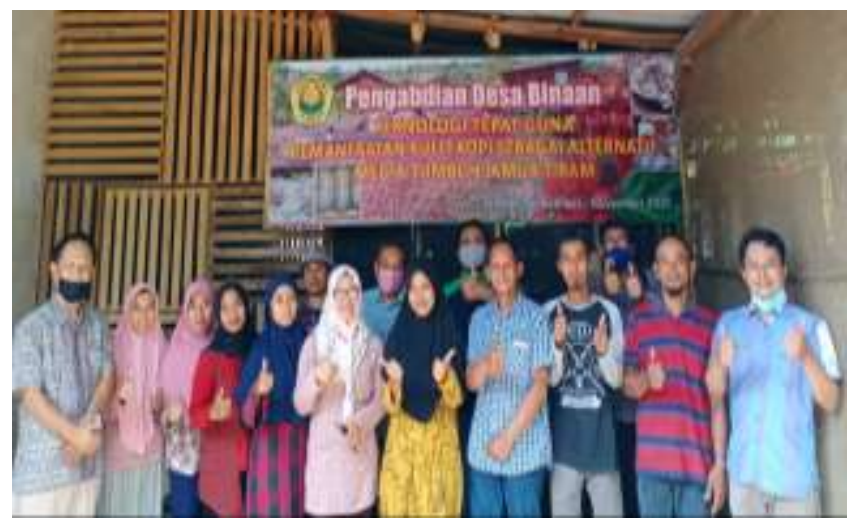

Gambar 11. Foto bersama tim dari universitas jember dan pemuda serta wanita tani

\section{KESIMPULAN}

1. Secara umum kegiatan pengabdian ini dirancang oleh Lembaga Penelitian dan Pengabdian Kepada Masyarakat (LP2M) Universitas Jember untuk memberi kontribusi nyata bagi masyarakat, khususnya dalam mengembangkan kesejahteraan dan kemajuan masyarakat atau petani kopi di Desa Sidomulyo.

2. Kegiatan survey dan sosialiasi dilaksanakan di awal kegiatan pada peserta sasaran. Beberapa informasi yang diperoleh dari kegiatan sosialisasi diantara yaitu selama ini kulit kopi hanya sebagai bahan tambahan pakan ternak kambing maupun sapi bagi petani yang memiliki ternak tersebut. Selain itu petani belum bisa memanfaatkan peluang bagaimana kulit kopi tersebut dapat menghasilkan uang tambahan jika diolah dengan baik menjadi produk yang bernilai jual tinggi.

3. Pelatihan teknik budidaya jamur tiram diawali pembekalan bagi sasaran mitra dengan memberikan pengetahuan cara membuat bag log media tumbuh jamur tiram dengan bahan utama yaitu limbah kulit kopi. Kegiatan ini dilakukan di Desa Karangharjo Kecamatan Silo.

4. Kegiatan pengabdian ini secara langsung memberikan hibah berupa bag log kepada mitra. Bag log yang akan disalurkan adalah bag log yang diolah 
masyarakat atau petani kopi bersama instruktur pembuatan bag log dengan bahan utama yaitu limbah kulit kopi.

5. Pendampingan dilakukan pada masyarakat atau petani kopi di Desa Sidomulyo dengan cara memberikan bekal materi terlebih dahulu terkait dengan cara bagaimana melakukan budidaya jamur yang baik dan benar. Selain itu juga pemahaman materi terkait dengan proses pemanenan jamur tiram perlu diberikan pada sasaran mitra.

\section{UCAPAN TERIMA KASIH}

Ucapan terima kasih disampaikan kepada Lembaga Penelitian dan Pengabdian kepada Masyarakat (LP2M) Universitas Jember melalui hibah Pengabdian Desa Binaan tahun 2020 dan kelompok tani.

\section{DAFTAR PUSTAKA}

BPS. (2019). Kecamatan Silo dalam Angka 2019. Jember: BPS.

Setiyono. (2009). Pemgembangan kewirausahaan produk dan pengolahan hasil jamur tiram dengan penerapan teknologi mesin pengepres media tipe dua silinder dan pemisah minyak sentrifugal. Jember: Lembaga Penelitian Universitas Jember.

Setiyono. (2009). Rancang bangun mesin pengepres bag log tipe empat tuas penekan dalam upaya peningkatan kualitas media tumbuh jamur tiram. Jember: Lembaga Penelitian Universitas Jember.

Setiyono. (2012). Pemanfaatan Berbagai Macam Limbah Bahan Organik Pada Budidaya Jamur Merang. Jember: Lembaga Penelitian Universitas Jember.

Setiyono, dkk. (2015). Pengembangan Teknologi Media Tumbuh Komoditas Jamur Dengan Pemanfaatan Limbah Tanaman. Jember: Lembaga Penelitian Universitas Jember.

Setiyono, dkk. (2019). Peningkatan Kualitas Kehidupan Dengan Pelatihan Budidaya dan Pengolahan Jamur Tiram di Desa Grujugan Lor, Kecamatan Jambesari Darus Sholah Kabupaten Bondowoso. Jember: Lembaga Penelitian Universitas Jember.

Sutarsih, dkk, (2018). Analisis Pemanfaatan Energi Surya dan Limbah Biomassa. Jember: Universitas Jember 